\title{
Managing Early Childhood Education
}

\author{
Cahyo Dwi Jatmiko ${ }^{1 *}$, Yasir Arafat ${ }^{2}$, Dessy Wardiah ${ }^{2}$
}

\author{
${ }^{1}$ PAUD TK Tunas Harapan Kec. Muara Telang \\ ${ }^{2}$ Universitas PGRI Palembang \\ *Corresponding author. E-mail: cahayaabadi8787@gmail.com
}

\begin{abstract}
This research is a descriptive qualitative study that aims to know and describe early childhood education management in Tunas Harapan Kindergarten, Muara Telang District. The research focuses on the management of institution, pupil, teaching staff, infrastructure and finance to improve quality of early childhood education in Tunas Harapan Kindergarten, Muara Telang District. The informants of this study are the principal, teachers, students. The data were collected through observation, interviews, and documentation. Then, they were analyzed using descriptive analysis techniques. This study found that the management of early childhood education at Tunas Harapan Kindergarten Muara Telang is generally good despite some aspects still need improvement.
\end{abstract}

Keywords: early childhood, early childhood education, early childhood education management

\section{INTRODUCTION}

Children have potentials that must be developed. Every child has specific characteristics and certainly different from one to another, especially with adults. Children tend to be active, dynamically enthusiastic and have a high level of curiosity for what they have just seen, heard, and felt. It seems that they cannotstop exploring and learning. Regarding their education, a good understanding of early the nature and foundation of childhood educationis important for anyone who directly or indirectly work children. Many parties influence their education including their family and others including the community, and policyholders ranging from the central government to the regions. It is expected that through a good understanding, the parties will be able to provide the good quality of education for early childhood [1].

Early childhood is an entire early period in the growth and development of human life. It is characterized by various vital periods that become the basis for the next child's life. One of the periods that characterize early childhood is the golden age period. The golden age period in early childhood is characterized by the emerging periods of exploration, identification/imitation.sensing, playing, and alter trozt or defiance.

The golden age concept is reinforced by neurologists who state that the baby's brain contains
100-200 billion neuron or nerve cells ready to connect between cells at birth. [2] said that brain tissue growth reaches $80 \%$ at the age of 3 years if many get stimulus, reach $85 \%$ at the age of 6 , and reach $100 \%$ culmination when the child is 8 to 18 years old. In line with the research results on brain development that until the age of 4 years, children's level of intelligence capability has reached $50 \%$. While at the age of 8 years reached $80 \%$ and the remaining about $20 \%$ obtained after the age of 8 years [4]. The functional growth of nerve cells requires various supportive educational situations, both in educational situations in families, communities, and schools. Education experts also agreed that if the golden period lasts only one time throughout the human life span. This shows that it is a loss for a family, society, and nation if it ignores early childhood critical times.

Early childhood education is a coaching effort aiming at children from birth to the age of six years, which is carried out through the provision of educational stimuli to help the growth and development of physical and spiritual so that children can enter further education. It is also mentioned in Law No. 20 of 2003 on the National Education System Article 1 Paragraph 14

Indonesia's Minister of Education and Culture Regulation Number 137 of 2014 on National Standards of Early Childhood Education states:

"Early childhood education is a level of education before the basic level of education which is a coaching effort aimed at children from birth to the age of six years which is 
carried out through the provision of educational stimuli to help the growth and development of physical and spiritual so that children have readiness in entering further education, which is held on formal, non-formal, and informal lines."

[12] stated that early childhood education is an effort to stimulate, guide, nurture, and provide learning activities that will produce children's skills and abilities at an early age. It is explained that early childhood education is the first step of a level of education that can help the development of children starting from birth to the age of six years so that the child has the readiness to continue his education to a higher level. Early childhood education is not emphasized solely on the provision of stimulus enrichment of children's knowledge but instead directed to the development of children's potential and creativity, and very importantly, on the formation of children's mental attitudes and personality the values of religious teachings. So it takes a place that accommodates children to grow and develop according to their age [9].

The development of qualified human resources improves physical abilities, which can be utilized to meet economic needs. According to [3], it is more important to develop capabilities focused on "brain power planning" that refers to the constellation of skills, attitudes, independent behavior, high competitiveness, and resistance to and turmoil from these changes. Also, [10] provides an overview of Indonesian human resources' quality expected in the third millennium is a human being aware of science and technology, creative human beings, and human beings' ethical solidarity.

In early childhood education programs, parents and teachers can work together to lead children into a great generation. However, the implementation of early childhood education is still facing various problems, so the concept of early childhood education began to shift. Experts also recommend the need to develop early childhood holistically and integrated. As stated in Presidential Regulation No. 60 of 2013 as follows "... implementation of Holistic-Integrative Early Childhood Development services towards the realization of healthy, intelligent, cheerful, and noble Indonesian children and the realization of the commitment of all relevant elements, namely parents, families, communities, governments and local governments, in the efforts of Holistic-Integrative Early Childhood Development."

To create quality human resources in the third millennium, education is the primary need that must be met. Education should be given from an early age because it is necessary to develop children's creativity early. The importance of education for early childhood is based on various studies stating that early childhood is a critical period of children's development. Based on neurological studies on birth, the baby's brain contains about 100 billion neurons ready to connect cells. During the first year, the baby's brain develops rapidly by producing trillions of connections between neurons that outnumber them. This connection must be strengthened through various psychosocial stimuli since incremental joints will experience atrophy (shrinkage) and perish. This is what will ultimately affect the child's level of intelligence. This has been proven by the research results at Baylor College of Medicine, which found that if a child rarely gets educational stimuli, his brain development is less than $20-30 \%$ of a child's average size. In another study, it was revealed that about $50 \%$ of human intelligence capability occurs when the child is four years old, $80 \%$ has occurred when he is eight years old, and reaches the culmination point when the child is about 18 years old. This means that the development that occurs in the next 14 years, and subsequently, the brain's development will stagnate.

Early childhood education development must be carried out in an integrated manner by paying attention to supporting aspects in implementing early childhood development programs in the community. In addition to helping the poor and breaking the cycle of poverty between generations, it is also expected to provide an educational intervention to increase children's survival chances. The combination of the two will optimize the growth and development of the child as a whole person, conducted through efforts to maintain health, provide nutrition, stimulate intelligence, provide extensive opportunities for children to explore and learn in a fun way, parenting and guidance of children to understand their potential and play an active role in the family and society.

Early childhood education should not be well delivered. We must first understand it well so that the objectives to be achieved can be realized perfectly. Eearly childhood education provides various learning experiences that optimize intelligence capabilities development of children. Broadly, it covers the entire psychosocial stimulation process that is not limited to classical learning. It means this type of education can occur anywhere and anytime, in family environment or educational institutions

Based on the various explanations that have been stated above, the existence of early childhood education institutions, both formal and non-formal, organized by the community becomes very important in providing stimuli that allow children to find things that go beyond their will. One type of education that pays attention to children's development is early childhood education institutions. Early childhood education is a vehicle with the concept of playing while learning, full of fun and freedom. Thus it allows children to express and develop their talents, interests, and creativity. At the same time, it also develops knowledge, skills, behavior and attitudes of the children.

The government, however, is facing many problems to develop early childhood education programs. First, the problems associated with funding. Second, the poor public understanding of the importance 
of early childhood education for children's development. Third, lack of staff who are able to handle early childhood education development atthe operational level. Fourth, there is still a lack of early childhood education personnel who are competent in their fields. In addition, infrastructure owned by institutions to support teaching and learning activities in schools is inadequate.

From the various descriptions presented above, we can know the various educational institutions' problems to improve learning quality.The quality of early hildhood education can not be separated from its management. Therefore, this study reported here aims to explore the management of early childhood education programs in the kindergarden Tunas Harapan Muara Telang District Banyuasin. Nowadays, many institutions organize early childhood education programs that last only 1-2 years. This is due to the problem of funding and a lack of coordination between institutions and surrounding communities. Also, educators still do not meet the full competence to teach in early childhood education schools.

In general, the case is a prevalent problem in the Banyuasin regency, especially in the Muara Telang subdistrict. Researchers have seen that in the Muara Telang subdistrict, there are approximately 30 early childhood education institutions spread across 16 villages, with three institutions in the form of private kindergartens, one state kindergarten, 26 informal Play Groups, and the rest there are institutions similar to early childhood education units. 30 of the institutions, are not accreditted.Tunas Harapan Kindergarten is the only one.

There are many factors why institutions have not yet recieved operational licenses. Management that is still far from the standard is one of the reasons. Another reason is the problem of funding. Researchers have found that some early childhood education institutions are forced to close due to funding problems and inadequate infrastructure. Further, most managers and educators were not well trained or educated for early childhood education Most of them just hold a high school graduate or undergraduate certificate that isnot linear with early childhood education.

This is different from Tunas Harapan Kindergarten, Muara Telang subdistrict, Banyuasin Regency. This school run quite well. In the learning process, it applies a student centered learning. Also it has sufficient number of teachers who are qualified, holding a teaching certificate in early childhood education. .

\section{METHODS}

This research applies a qualitative approach. [4] defines qualitative methodology as a research procedure that produces descriptive data in written or spoken words from people and observable behavior. This approach is holistic (whole) and individuals [7] [5]. Accordingly, it should not isolate individuals or organizations into variables and hypotheses, but it is necessary to look at them at their context.

This qualitative approach requires researchers as the key instruments in extracting information from research subjects. The key informant in this study was the principal. The study's subject in question is the main person carrying out his duties and responsibilities that can be observed from the behavior displayed. Behaviors routinely performed can be approaches, activities, efforts, roles articulated or actualized by research subjects. Then the researchers gave a qualitative and indepth explanation (werstehen).

\section{RESULTS AND DISCUSSION}

The results showed that the Tunas Harapan kindergarten programs were managed according to its vision and mission by applying management functions including; planning, implementation, supervision, and evaluation. As leaders in carrying out management functions, managers strongly emphasize cooperation based on sincerity, spirit, and high loyalty. Planning is done by developing strategic and operational planning. Organizing is carried out by coordinating tasks, opportunities, experiences, and insights with open communication, holding regular meetings that discuss performance improvement efforts. Supervision is carried out by direct observation, regular meetings with educators. Cooperation is carried out with parents through monthly meeting activities (parenting) and school-related partners. Finally, assessment and evaluation are carried out by assigning assignments, observations, diaries, anecdotes, performances, works, educational visits, and developmental information through students' health records.

According to Suharti (2018: 1), good educational facilities and infrastructure are essential to provide comfortable learning environment for children. Here, safety should be attention as well as the applicable regulations, and standards as set by the government. Facilities and infrastructure should be available indoor and outdoor as a learning tool for students that are provided considering the students' development level. In line with [2], it will undoubtedly hinder the learning process without adequate facilities and infrastructure. This explains that facilities and infrastructure become essential to support various aspects so that children are more passionate about playing and learning with adequate facilities.

At Tunas Harapan Kindergarten, students are grouped by age as follows

- $\quad$ Age 2-4: Group C

- Age 4-5: Group A

- Age 5-6: Group B

For the allocation of time adjusted to the age, namely:

- $\quad$ Group of 2-4 years: One meeting for 150 - 180 minutes 
- $\quad$ Group of 4-6 years: one meeting: 180 minutes Comparison between educators and students:

- Group 2-4 : 1: 10 children

- Group of 4-6 years: 1: 15 children.

The curriculum used in Tunas Harapan Kindergarten is a K-13 curriculum where a scientific approach applied. It aims to help children in all aspects of life skills and instill habits about learning how to learn (learning to learn). Curriculum changes are also inseparable from policymakers' role, especially the government in education. In teaching, teachers should refer to In K-13 mandates:

1. The achievement level of early childhood development

2. Results-oriented learning

3. Using a varied method approach

4. Learning resources are not teacher-focused but child-centered.

5. Assessment is emphasized on the process that occurs during the activity and not on learning outcomes (continuous).

Several advantages have in learning on K-13 so that it is still a reference, including:

a. K-13 includes development on curriculum structure, learning process with a scientific approach, and authentic assessment.

b. This curriculum carries the development of constructive learning that is more flexible to give children space to develop their talents and potentials.

c. The curriculum approach model aims to form attitudes, knowledge, and skills of learners that are more consistent and fundamental for learners to be better prepared to continue to a higher education level.

d. Class is not the only place to learn.

e. Learning resources are not just teachers and books.

f. Learning with creativity.

g. Invite the child to be observant of his curiosity.

h. They were making children like to ask questions because of their curiosity about education success in school, judging by education quality.

i. To be a mediator or liaison between parents' aspirations to the school and participate in socializing school policy to the relevant parties and authorities at the regional level.

j. Invite students to find out instead of being told.

k. Train leadership.

1. Realizing students have a typical.

$\mathrm{m}$. Prioritize the understanding of language.

Curriculum 2013 in Early Childhood Education was developed based on various studies, both theoretically, empirically, juridically, and socio-culturally. The learning program covers six aspects: religious and moral values, cognitive, social-emotional, language, motor physical, and art, adjusted to the standard level of child development achievement [11] [13].

\section{CONCLUSION}

Management is about managing, controlling, and coordinating organisational resources to achieve the expected goals. In Tunas Harapan kindergarten, education management includes planning, implementation, supervision, and coaching. Following is the conclusion of the findings :

1. Management of the early childhood education classifies eductional services into two: kindergarten and playgroups. These services well organized so that students are happy to learn there. Also, the provision of these services has met the standards of service and of learners' and community's needs. However, some aspects of the services still need improvement.

2. Student management carried out at Tunas Harapan Kindergarten has been carried out to achieve the development level of children as planned. The learning process is run with consideration of students' age group, community's needs and the students' characteristics. The implementation of student management begins with assessing children's development, carried out by teachers with the principal's direction. The asessment results are then given to parents

3. The management of teachers and staff at Tunas Harapan Kindergarten has been done well. Teachers and staff meet standards, even exceed the national standards of education personnel. Teachers and staff at Tunas Harapan kindergarten are qualified as early childhood educators. All teachers have attended the basic training early childhood education held by the Banyuasin District Education Office. The teachers hold bachelor in early childhood education. Only one teacher is still pursuing a bachelor's degree. All teachers were allowed to study and attend training. The principal himself is also qualified. He is a civil servant with sufficient teaching experience as he has started teaching early childhood since 1990.

4. The facility management in Tunas Harapan kindergarten has been well implemented. However, buildings and facilities for children to play still need improvement

5. Financial management in Tunas Harapan kindergarten follows the regulations and rules of financial management for early childhood education. As the person in charge of Tunas Harapan kindergarten's financial management, the principal tries to do the best.The management of operational costs obtained from the Regional Budget And Expenditure Grants also follows the guidelines of budget allocation. The principal talks to parents if 
there is a lack of funding. Tunas Harapan kindergarten also receive funding from the community.

\section{REFERENCES}

[1] Barnawi., \& Arifin, M. (2012). Manajemen Sarana Dan Prasarana. Jogjakarta: Arruzz Media

[2] Darmayanti, M. (2016). Manajemen Program Satuan Di PAUD SPS Edelweis Kelurahan Tridadi Sleman Yogyakarta. UNY. Yogyakarta.

[3] Hapidin (2012) Manajemen Pendidikan TK/PAUD. Universitas Terbuka: Tangerang Selatan.

[4] Moleong. L. J. (2007). Metodologi Penelitian Kualitatif. Bandung. Rosdakarya.

[5] Mulyana, D. (2012). Metodologi Penelitian Kualitatif Paradigma Baru Ilmu Komunikasi Dan Ilmu Sosial Lainnya. Bandung : PT Remaja Rosdakarya.

[6] Mulyasa. (2017). Strategi Pembelajaran PAUD. Bandung: PT Remaja Rosdakarya.
[7] Sugiyono. (2012). Metode Penelitian Kuantitatif, kualitatif, dan R\&D. Cetakan ke-17. Bandung: Alfabeta.

[8] Suharti. (2018). Manajemen Pendidikan Anak Usia Dini Dalam Rangka Meningkatkan Mutu Pembelajaran (Studi Kasus Pada PAUD Negeri Pembina Curup Dan PAUD Pertiwi Rejang Lebong. Jurnal Studi Manajemen Pendidikan. Vol. 2. No. 1 . STAIN. Curup.

[9] Suharni. (2019). Manajemen Pendidikan Anak Usia Dini Pada PAUD Bintang Rabbani Pekanbaru. Jurnal Ilmiah Potensia, Vol. 4 (1), 1-5

[10] Sufyarma. (2003). Kapita Selekta Manajemen Pendidikan. Bandung: Alfabeta.

[11] Trianto. (2011). Desain Pengembangan

[12] Wiyani., \& Barnawi. (2014). Format PAUD. Jogjakarta: Ar-ruzz Media

[13] Tematik Bagi Anak Usia Dini TK/RA \& Anak Usia Kelas Awal SD/MI. Jakarta : Kencana 